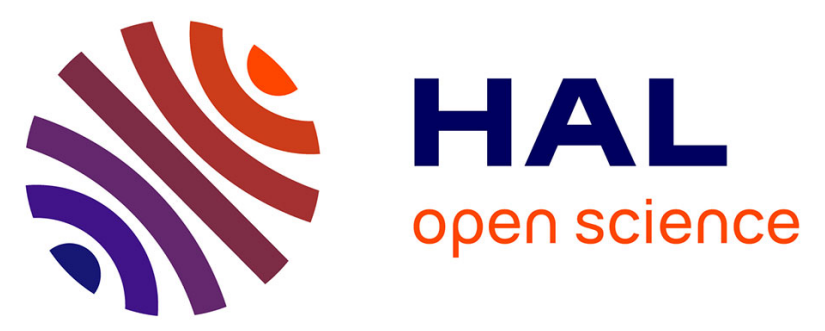

\title{
Malmgrenia louiseae sp. nov., a new scale worm species (Polychaeta: Polynoidae) from southern Europe with a key to European Malmgrenia species
}

Jérôme Jourde, Leandro Sampaio, Ruth Barnich, Paulo Bonifácio, Céline Labrune, Victor Quintino, Pierre-Guy Sauriau

\section{To cite this version:}

Jérôme Jourde, Leandro Sampaio, Ruth Barnich, Paulo Bonifácio, Céline Labrune, et al.. Malmgrenia louiseae sp. nov., a new scale worm species (Polychaeta: Polynoidae) from southern Europe with a key to European Malmgrenia species. Journal of the Marine Biological Association of the UK, 2015, 95 (5), pp.947-952. 10.1017/S0025315414001878 . hal-01245380

\author{
HAL Id: hal-01245380 \\ https://hal.science/hal-01245380
}

Submitted on 17 Dec 2015

HAL is a multi-disciplinary open access archive for the deposit and dissemination of scientific research documents, whether they are published or not. The documents may come from teaching and research institutions in France or abroad, or from public or private research centers.
L'archive ouverte pluridisciplinaire HAL, est destinée au dépôt et à la diffusion de documents scientifiques de niveau recherche, publiés ou non, émanant des établissements d'enseignement et de recherche français ou étrangers, des laboratoires publics ou privés. 
Malmgrenia louiseae sp. nov., a new scale worm species (Polychaeta: Polynoidae) from Southern Europe with a key to European Malmgrenia species.

Jérôme Jourde $^{1^{*}}$, Leandro Sampaio ${ }^{2}$, Ruth Barnich ${ }^{3,4}$, Paulo Bonifácio ${ }^{5,6}$, Céline Labrune ${ }^{6}$, Victor Quintino $^{2}$ and Pierre-Guy Sauriau ${ }^{1}$

1 Littoral Environnement et Sociétés UMR 7266 CNRS/Université de La Rochelle, Observatoire de la Biodiversité Faune et Flore des Pertuis Charentais (OBIONE), 2 rue Olympe de Gouges, 17000 La Rochelle, France

2 Department of Biology and CESAM, University of Aveiro, 3810-193 Aveiro, Portugal

3 Thomson Unicomarine Ltd., Compass House, Guildford GU2 7AG, United Kingdom

4 Senckenberg Research Institute \& Natural History Museum, Senckenberganlage 25, D60325 Frankfurt, Germany

5 Environnements et Paléoenvironnements Océaniques et Continentaux, UMR 5805 CNRS/Université Bordeaux, Station Marine d'Arcachon, 2 rue du professeur Jolyet, 33120 Arcachon, France

6 Laboratoire d'Ecogéochimie des Environnements Benthiques, UMR 8222 CNRS/Université Pierre et Marie Curie Paris VI, Observatoire Océanologique de Banyuls, Avenue du Fontaulé, 66650 Banyuls-sur-Mer, France

* Corresponding author jjourde@univ-lr.fr

Malmgrenia louiseae sp. nov. is described from both the Western Mediterranean in the Gulf of Lions, and the North-east Atlantic from off Portugal and the Bay of Biscay. The species was found in muddy sediments in shallow water and is possibly associated with echiurids or synaptid holothurians. Malmgrenia louiseae sp. nov. can be clearly distinguished from all other known Malmgrenia species by the presence of an infra-acicular process in addition to the supra-acicular process on the acicular lobe of the neuropodia, the lack of microtubercules on the elytra, two kinds of notochaetae (stout with blunt tip and slender with fine pointed tip), and exclusively unidentate neurochaetae. An identification key to the North-east Atlantic and Mediterranean Malmgrenia species is provided.

Key words: Polychaeta, Polynoidae, Taxonomy, Malmgrenia, Mediterranean, North-east Atlantic, Associations

\section{INTRODUCTION}

Five programs monitoring benthic communities, independently carried out in the Gulf of Lions, Mediterranean, in Portuguese waters and in the Pertuis Charentais part of the Bay of Biscay led to the collection of several specimens of an unknown polynoid species. The review 
of these specimens during the $4^{\text {th }}$ RESOMAR Benthos Taxonomic Workshop held in June 2013 in La Rochelle revealed that they belong to a hitherto unknown Malmgrenia species. So far 10 species of Malmgrenia McIntosh, 1874 have been reported from the Mediterranean and the North-east Atlantic to which the new species M. louiseae sp. nov., described herein, has to be added (Table 1). They were either attributed to the genus Malmgrenia McIntosh, 1874 or Malmgreniella Hartman, 1967 by their respective original author and there has been some controversy in the literature regarding the correct generic name to be used (Barnich \& Fiege, 2001; Muir \& Chambers, 2008). Following ICZN Opinion 2233 (2009), which ruled that the usage of the generic name Malmgrenia McIntosh, 1874 is to be conserved, at least the North-east Atlantic and Mediterranean species should now be attributed to this genus. Most of these species are known to live in association with echinoderms and other invertebrates such as tubicolous or terricolous species (Barel \& Kramers, 1977; Pettibone 1993). The potential associates are reported and a key to all Malmgrenia species found in the area is given.

\title{
MATERIAL AND METHODS
}

The specimens were collected from subtidal grab samples (Van Veen or Smith-McIntyre) in the following surveys or inventories of benthic macrofauna communities: CARTHAM in the Mediterranean (ASCONIT, 2012), Guia marine outfall monitoring program, ACOSHELF and MeshAtlantic in Portuguese waters, OBIONE in Bay of Biscay (Table 2; Figure 1).

The samples were washed with sea water onboard on a $1 \mathrm{~mm}$ mesh size and fixed in a $4 \%$ formalin-sea water solution. They were sorted in the laboratory and the specimens preserved in a $70 \%$ ethanol solution. All observations and measurements were carried out on fixed specimens. The animals were very fragile and most of the elytra were lost and bodies fragmented during the washing steps. Also, body fragmentation and elytra losses occurred when live specimens were added to freshwater or alcohol.

The preserved specimens were studied and photographed using a stereomicroscope Leica M205C coupled to a digital camera Leica IC80HD and the Leica Application Software. Details of elytra and parapodia needed the use of a compound microscope (Leica DMIRB, coupled with a digital camera Olympus DP70 and the DP Controller software). The photographs of the holotype were used as basis for drawings of the animal with the free vector graphics editor Inkscape.

Length $(\mathrm{L})$ was measured from the anterior margin of the prostomium to the posterior border of the last segment (pharynx not included, if everted) and width (W) was taken at the widest segment, including parapodia but excluding chaetae.

The type material is deposited in the collections of the Muséum National d'Histoire Naturelle de Paris, France (MNHN), the Museu Nacional de História Natural e da Ciência de Lisboa, Portugal (MNHNC-UL) and the Senckenberg Museum Frankfurt, Germany (SMF).

\author{
SYSTEMATICS \\ Family POLYNOIDAE Kinberg, 1856 \\ Genus Malmgrenia McIntosh, 1874
}

TYPE SPECIES Malmgrenia andreapolis McIntosh, 1874

DiAGNOSIS (emended to include new species described herein) 
Body flattened dorsoventrally, short, up to 46 segments, more or less covered by elytra or short tail uncovered (large specimens). Elytra 15 pairs on segments 2, 4, 5, 7, 9, 11, 13, 15, $17,19,21,23,26,29,32$. Prostomium bilobed, without distinct cephalic peaks, with three antennae; lateral antennae with ceratophores inserted terminoventrally; two pairs of eyes, anterior pair usually dorsolaterally in front of widest part of prostomium, posterior pair dorsally near hind margin of prostomium. Parapodia biramous, noto- and neuropodia with elongate acicular lobe; tips of noto- and neuroacicula penetrating epidermis; neuropodia with or without supra-acicular or sub-acicular process. Notochaetae with rows of spines and blunt or pointed tips; neurochaetae more numerous, with rows of spines only distally and one or two kinds of tips: bidentate with secondary tooth subdistally and/or unidentate with pointed or knob-like tip.

\section{Malmgrenia louiseae sp. nov. (Figure 2)}

\section{TYPE MATERIAL}

Holotype: 1 complete specimen (cs) (MNHN POLY TYPE 1559), L $13.7 \mathrm{~mm} \mathrm{~W} 4.3 \mathrm{~mm}$ for 33 segments (fragmented); Gulf of Lions, Côte Catalane, CARTHAM B50, 24 August 2010, 309' 57' 'E 42 35' 19,6'’ N; 56 m, coastal mud, leg. C. Labrune and J-M. Amouroux. Paratypes: $1 \mathrm{cs}$ (MNHN POLY TYPE 1560), L $10.5 \mathrm{~mm}$ W $3.7 \mathrm{~mm}$ for 32 segments (fragmented); Bay of Biscay, Pertuis Charentais, OBIONE, Antioche, 22 August 2011, $1^{\circ} 18^{\prime} 30^{\prime}$ 'W $46^{\circ} 05^{\prime} 03$ 'N, $35 \mathrm{~m}$, coastal muddy sand, leg. J. Jourde and P-G. Sauriau. 1 cs (SMF 23918), L $12.5 \mathrm{~mm} \mathrm{~W} 3.8 \mathrm{~mm}$ for 34 segments (fragmented); Bay of Biscay, Pertuis Charentais, OBIONE, Antioche, 28 March 2012, 1'18'30' 'W 4605'03'N, 35 m, coastal muddy sand, leg. J. Jourde and P-G. Sauriau.

1 cs (MB29-000340), L 22 mm W 5 mm for 36 segments (fragmented); off Portugal, CascaisGuia G29(2), October 2008, 9²4’58.50’'W 38 39'37.86"N, 34 m, mud, leg. L. Sampaio and V. Quintino.

2 anterior fragments (MB29-000340), L $5.5 \mathrm{~mm} \mathrm{~W} 4.5$ for 12 segments and L $3 \mathrm{~mm} \mathrm{~W} 2.5$ mm for 11 segments; off Portugal, Cascais-Guia G29(2), October 2008, 9²4'58.50” W $38^{\circ}$ 39' 37.86"N, 34 m, mud, leg. L. Sampaio and V. Quintino.

\section{DiAGNOSIS}

Elytral surface smooth, microtubercules totally absent, outer lateral elytral margin with few small scattered papillae, posterior margin with fewer short papillae; neuropodia with an infraacicular process in addition to the supra-acicular process; two types of notochaetae: upper ones stout with blunt tips and lower ones slender with very pointed tips; neurochaetae all unidentate, upper tapering to long, pointed tips.

\section{DESCRIPTION (based on holotype)}

Prostomium bilobed, without cephalic peaks; median antenna with ceratophore in anterior notch, style papillate, tapering to filiform tip; lateral antennae with ceratophores inserted terminoventrally and with papillate, tapering styles; palps smooth, long, tapering; anterior pair of eyes dorsolaterally in front of widest part of prostomium, posterior pair dorsally near hind margin (Figure 2A). Tentaculophores inserted laterally to prostomium, without chaetae, with a pair of papillate dorsal and ventral tentacular cirri, tapering to filiform tip. Second segment with first pair of elytra, biramous parapodia, ventral buccal cirri obviously longer than the following ventral cirri, papillate. 15 pairs of elytra for 33 chaetigers; elytra delicate, surface smooth; outer lateral and posterior elytral margin with few short papillae; surface near the outer lateral margin with very few scattered surface papillae of variable length (some as long as the largest marginal papillae); faint pigmentation in form of isolated spot near place of 
attachment of elytrophore and on the inner lateral part (Figure 2B-C). Styles of dorsal cirri papillate, tapering to filiform tip, extending beyond tips of neurochaetae; styles of ventral cirri with few papillae, tapering, shorter than neuropodia (Figure 2D). Parapodia biramous, both rami with single aciculum penetrating epidermis; notopodia with short, inconspicuous rounded preacicular lobe and longer, pointed acicular lobe; neuropodia with subconical prechaetal acicular lobe with longer, digitiform supra-acicular process and shorter, but conspicuous sub-acicular process, postchaetal lobe rounded (Figure 2D). Notochaetae with distinct rows of spines and of two kinds: upper ones stout with blunt tip and lower ones slender, tapering to very fine tip, (Figure 2 E1-E2); neurochaetae with rows of spines only in distal part; upper tapering to long, pointed, unidentate tip, lower ones with short bent enlarged distal part ending in blunt tip, middle ones of intermediate shape with blunt distal part (Figure 2 E3-E5).

\section{HABITAT}

The species is currently known from muddy substrates, between 34 to $110 \mathrm{~m}$ depth (Table 2). Several potential hosts were found in the stations where the new species was collected. Thus, most of the Portuguese specimens were caught with the echiurid Thalassema thalassemum (Pallas, 1766) and one with the synaptid holothurian Leptosynapta inhaerens (O. F. Müller, 1776). However, specimens of Malmgrenia louiseae sp. nov. were never observed in immediate contact with the echiurid or the holothurian. In the Bay of Biscay, all the specimens were collected with Leptosynapta cf. bergensis (Östergren, 1905) and one specimen was observed in contact with the holothurian. The Mediterranean specimens were collected with the synaptid Oestergrenia digitata (Montagu, 1815).

\section{DISTRIBUTION}

Currently known from type locality in the Western Mediterranean (Gulf of Lions) and Northeast Atlantic: Portuguese coasts (Cascais-Guia, Costa da Caparica and Figueira da Foz) and Bay of Biscay (Pertuis Charentais).

\section{ETYMOLOGY}

The species is named in honor of Louise Jourde, first author's daughter, born a few months before the beginning of this work.

\section{REMARKS}

Malmgrenia louiseae sp. nov. is unique due to its neuropodial sub-acicular process present in addition to the supra-acicular process which is known from several other Malmgrenia and many other polynoid species. It might be confused with Malmgrenia lilianae (Pettibone, 1993), a species originally described from the South-west Atlantic (Pettibone, 1993), then reported for the Mediterranean (Barnich \& Fiege, $2001 \& 2003$ ) and now also recorded from North-east Atlantic off Portugal (unpublished) and in Bay of Biscay (unpublished). In both species elytra are devoid of microtubercles, with marginal papillae, and neurochaetae are exclusively unidentate. However, in M. lilianae there is only one kind of notochaetae (stout with pointed tip) and the sub-acicular process is absent. The identification key given below highlights further differences to other species in Europe.

\section{Key to North-EASt ATLANTIC AND MEDITERRANEAN MALMGRENIA SPECIES}

1. Elytral margin with many long papillae... 2

- Elytral margin with few scattered papillae or margin smooth ......................................... 3 
2. Elytral surface covered more or less completely by microtubercles; neurochaetae all unidentate, tapering to long, pointed tips, supra-acicular process digitiform M. polypapillata

- Elytral surface with patch of microtubercles in anterior part; neurochaetae bi- and unidentate; supra-acicular process absent M. mcintoshi

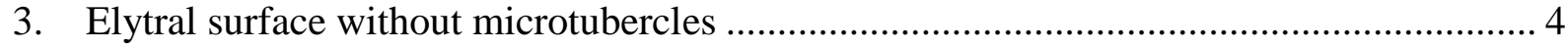

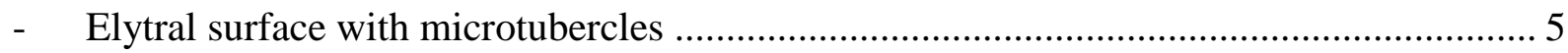

4. Neuropodial acicular lobe with digitiform to conical supra-acicular process; short and long notochaetae stout with pointed tip; neurochaetae unidentate M. lilianae

- Neuropodial acicular lobe distally bilobed with digitiform to conical supra-acicular process and shorter sub-acicular process; short notochaetae with blunt tip, long notochaetae with slender, pointed tip; neurochaetae unidentate ............ louiseae sp. nov.

5. Elytral surface covered more or less completely by microtubercles, neurochaetae usually all bidentate M. ljungmani

- Elytral surface with patch of microtubercles in anterior part; neurochaetae bi- and unidentate

6. Neuropodia without supra-acicular process

M. marphysae

- $\quad$ Neuropodia with supra-acicular process 7

7. Short notochaetae stout, with blunt tip; long notochaetae slender, with pointed tip; upper and middle neurochaetae bidentate, lower unidentate M. darbouxi

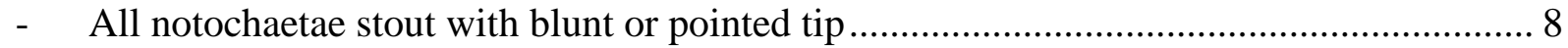

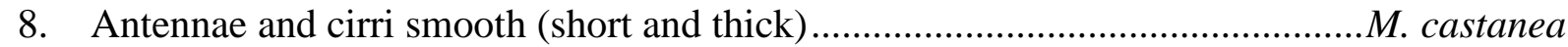

- Antennae and cirri papillate

9. Supra-acicular process small, digitiform.

M. lunulata

- Supra-acicular process wide bulbous or subconical

10. Neurochaetae usually all bidentate, unidentate neurochaetae (if present) with pointed tip . M. arenicolae

- Upper and lower neurochaetae usually unidentate with knob-like tip, middle neurochaetae bidentate M. andreapolis

\section{ACKNOWLEDGMENTS}

JJ was financially supported by the Région Poitou-Charentes through CPER funding, the Université de La Rochelle and CNRS. LS and VQ were supported by the research projects "ACOSHELF" (POCI/MAR/56441/2004-PPCDT/MAR/56441/2004), "Monitorização Ambiental do Emissário Submarino e da ETAR da Guia do Sistema de Saneamento da Costa 
do Estoril", funded by SANEST, S.A., "MeshAtlantic" (with the support of the European Union ERDF-Atlantic Area Program 2009-1/110) and by European Funds through COMPETE and National Funds through the Portuguese Science Foundation (FCT) within project PEst-C/MAR/LA0017/2013. LS benefited from a Post-doc grant (SFRH/BPD/72997/2010), given by FCT (Fundação para a Ciência e Tecnologia). The Mediterranean data used in this paper are part of the $\mathrm{PhD}$ Thesis of $\mathrm{PB}$ funded by IFREMER (convention 09/3211321) and the Agence de l'Eau Corse-Méditerranée (convention $\mathrm{n}^{\circ} 2010$ 0871). They were obtained during the monitoring program CARTHAM funded by the Agence des Aires Marines Protégées and managed as a part by the GIS Posidonie.

LS and VQ would like to thank Susan Chambers, National Museums of Scotland (UK) for commenting on the identity of the new species at an earlier stage. JJ and PGS gratefully thank Fabien Aubert, Nicolas Lachaussée, Philippe Pineau and the captain of the coastal N.O. "Estran" Vincent Ottmann for their help during the sampling sessions. JJ also thanks Hélène Agogué and Eric Pante for their valuable comments. CL and PB thank the captains and crew members of N.O. Thetys II and Alicia Romero Ramirez for assistance during samplings and Jean-Michel Amouroux for help during identification.

Authors are grateful to the two anonymous referees for their corrections and valuable comments that improved the manuscript.

\section{REFERENCES}

ASCONIT Consultants, UPVD, ADENA, OCEANIDE and LECOB (2012) Diagnostique scientifique des habitats marins du PNM Golfe du Lion. Programme CARTHAM. Agence des Aires Marines Protégées. Publ. Fr. : 410 pp.

Barel C.D.N. and Kramers P.G.N. (1977) A survey of the echinoderm associates of the North-east Atlantic area. Zoologische Verhandelingen 156: 1-159.

Barnich R. and Fiege D. (2001) The Mediterranean species of Malmgreniella Hartman, 1967 (Polychaeta: Polynoidae: Polynoinae), including the description of a new species. Journal of Natural History 35, 1119-1142.

Barnich, R. and Fiege, D. (2003) The Aphroditoidea (Annelida: Polychaeta) of the Mediterranean Sea. Abhandlungen der Senckenbergischen Naturforschenden Gesellschaft 559: 1-167.

ICZN Opinion (2009) Opinion 2233 (Case 3417) Malmgrenia McIntosh, 1874 (Annelida, Polychaeta, Polynoidae): usage conserved. Bulletin of Zoological Nomenclature 66(4), $1-3$.

Muir A.I. and Chambers S.J. (2008) Case 3417 Malmgrenia McIntosh, 1874 (Annelida, Polychaeta, Polynoidae): proposed conservation of usage by designation of Malmgrenia andreapolis McIntosh, 1874 as the type species. Bulletin of Zoological Nomenclature 65(1), 12-16.

Pettibone, M.H. (1993) Scaled Polychaetes (Polynoidae) associated with Ophiuroids and other invertebrates and review of species referred to Malmgrenia McIntosh and replaced by Malmgreniella Hartman, with description of new taxa. Smithsonian Contributions to Zoology 138: 1-92. 
Figure captions

Table 1. Malmgrenia species known to occur in the Mediterranean and North-East Atlantic (cf. Barnich \& Fiege 2001 \& 2003; Barnich 2011; Pettibone 1993).

Table 2. Localities, geographical coordinates (WGS 84), sediment, depth, number of specimens collected and sampling dates of Malmgrenia louiseae sp. nov.

Figure 1. Sampling locations of Malmgrenia louiseae sp. nov. between 2002 and 2012.

Figure 2. Malmgrenia louiseae sp. nov., holotype (MNHN POLY TYPE 1559): (A) anterior end, dorsal view; (B) left middle elytron $\left(9^{\text {th }}\right)$; (C) detail of lateral margin of same; (D) right cirrigerous parapodium of chaetiger 12, posterior view; (E) chaetae, E1: upper notochaetae, E2: lower notochaetae, E3: upper neurochaetae, E4: middle neurochaetae, E5: lower neurochaetae. Scale bars: A, 1 mm; B, D, $500 \mu \mathrm{m}$; E1, E2, C, $100 \mu \mathrm{m}$; E3, E4, E5, $50 \mu \mathrm{m}$. 


\begin{tabular}{lcc}
\hline Species & Mediterranean & North-East Atlantic \\
\hline M. andreapolis McIntosh, 1874 & $\mathrm{X}$ & $\mathrm{X}$ \\
M. arenicolae (de Saint Joseph, 1888) & $\mathrm{X}$ & $\mathrm{X}$ \\
M. castanea McIntosh, 1876 & $\mathrm{X}$ & $\mathrm{X}$ \\
M. darbouxi (Pettibone, 1993) & $\mathrm{X}$ & $\mathrm{X}$ \\
M. lilianae (Pettibone, 1993) & $\mathrm{X}$ & $\mathrm{X}$ \\
M. ljungmani (Malmgren, 1867) & $\mathrm{X}$ & $\mathrm{X}$ \\
M. louiseae sp. nov. & $\mathrm{X}$ & $\mathrm{X}$ \\
M. lunulata (Delle Chiaje, 1830) & & $\mathrm{X}$ \\
M. marphysae McIntosh, 1876 & $\mathrm{X}$ & $\mathrm{X}$ \\
M. mcintoshi Tebble \& Chambers, 1982 & & \\
M. polypapillata (Barnich \& Fiege, 2001) & &
\end{tabular}

311

312 Table 2.

\begin{tabular}{|c|c|c|c|c|c|}
\hline Localities & Coordinates & Sediment & Depth & $\mathbf{N}$ & Month/Year \\
\hline Cascais-Guia & $\begin{array}{c}38^{\circ} 39^{\prime} 33.66^{\prime \prime} \mathrm{N} \\
09^{\circ} 28^{\prime} 34.32^{\prime \prime} \mathrm{W}\end{array}$ & mud & $76 \mathrm{~m}$ & 1 & $10 / 02$ \\
\hline Cascais-Guia & $\begin{array}{ccc}38^{\circ} 39^{\prime} & 37.86^{\prime \prime} \mathrm{N} \\
09^{\circ} 24^{\prime} & 58.50^{\prime \prime} \mathrm{W}\end{array}$ & mud & $34 \mathrm{~m}$ & 1 & $10 / 02$ \\
\hline Cascais-Guia & $\begin{array}{c}38^{\circ} 39^{\prime} 37.86^{\prime \prime} \mathrm{N} \\
09^{\circ} 24^{\prime} 58.50^{\prime \prime} \mathrm{W}\end{array}$ & mud & $34 \mathrm{~m}$ & 7 & 01/06, 10/08, 09/09 \\
\hline Cascais-Guia & $\begin{array}{lll}38^{\circ} 39^{\prime} & 31.62^{\prime \prime} \mathrm{N} \\
09^{\circ} 26^{\prime} & 06.36^{\prime \prime} \mathrm{W}\end{array}$ & mud & $48 \mathrm{~m}$ & 1 & $10 / 07,10 / 08$ \\
\hline Cascais-Guia & $\begin{array}{l}38^{\circ} 39^{\prime} 33.66^{\prime \prime} \mathrm{N} \\
09^{\circ} 28^{\prime} 34.32^{\prime \prime} \mathrm{W}\end{array}$ & mud & $76 \mathrm{~m}$ & 1 & $10 / 08$ \\
\hline Costa da Caparica & $\begin{array}{l}38^{\circ} 31^{\prime} 29.81^{\prime \prime} \mathrm{N} \\
09^{\circ} 22^{\prime} 01.26^{\prime \prime} \mathrm{W}\end{array}$ & mud & $110 \mathrm{~m}$ & 1 & 04/08 \\
\hline Figueira da Foz & $\begin{array}{lll}40^{\circ} 02^{\prime} & 18.23^{\prime \prime} \mathrm{N} \\
09^{\circ} 10^{\prime} & 28.50^{\prime \prime} \mathrm{W}\end{array}$ & mud & $100 \mathrm{~m}$ & 1 & $06 / 10$ \\
\hline Gulf of Lions, Côte Catalane & $\begin{array}{l}42^{\circ} 35^{\prime} 19.60^{\prime \prime} \mathrm{N} \\
03^{\circ} 09^{\prime} 57.00^{\prime \prime} \mathrm{E}\end{array}$ & sandy mud & $56 \mathrm{~m}$ & 2 & $08 / 10$ \\
\hline Bay of Biscay, Pertuis Charentais & $\begin{array}{l}46^{\circ} 05^{\prime} 03.00^{\prime \prime} \mathrm{N} \\
01^{\circ} 18^{\prime} 30.00^{\prime \prime} \mathrm{W}\end{array}$ & sandy-mud & $38 \mathrm{~m}$ & 15 & $08-09-10 / 11,01-02-03 / 12$ \\
\hline
\end{tabular}




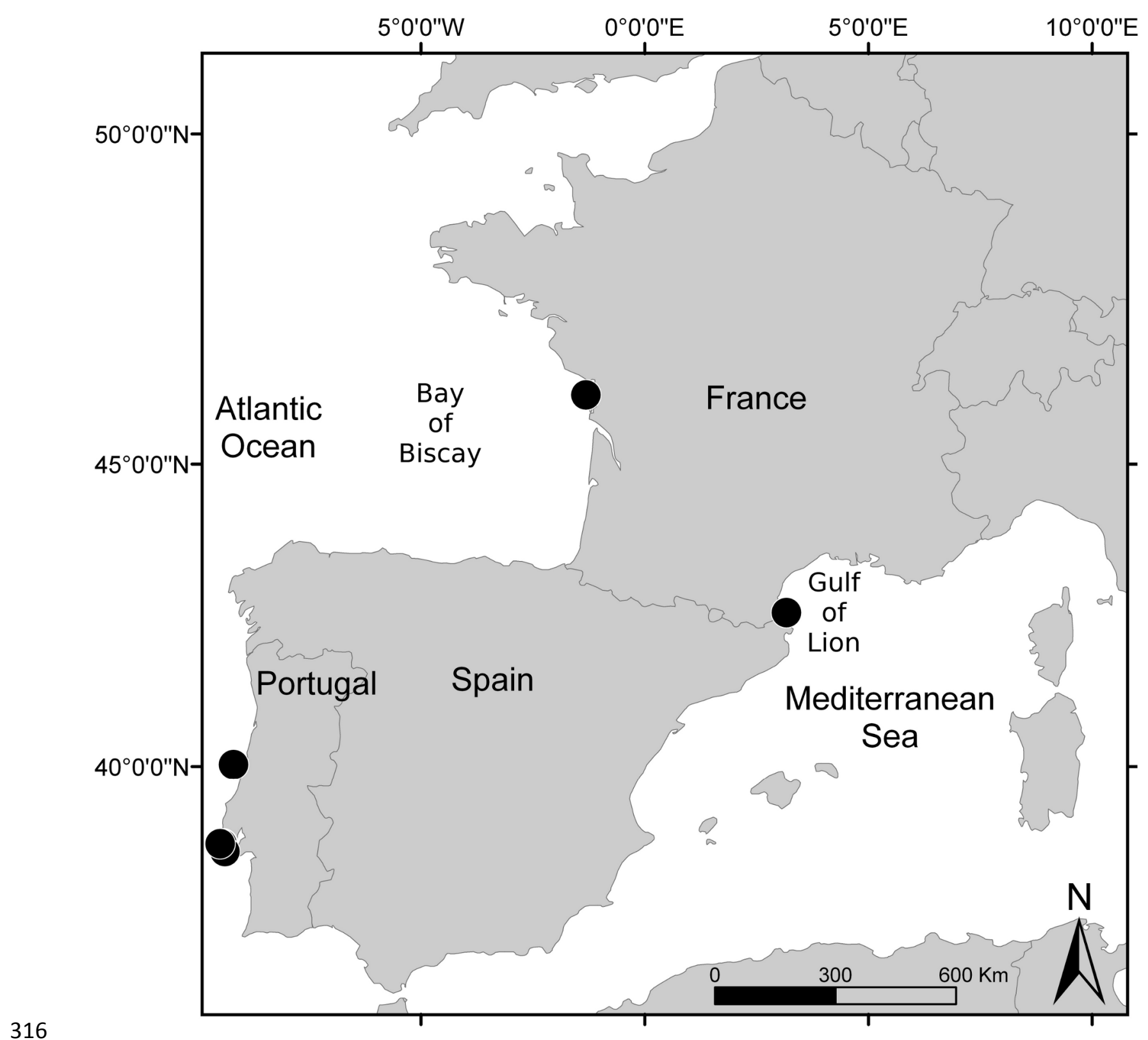


Figure: 2
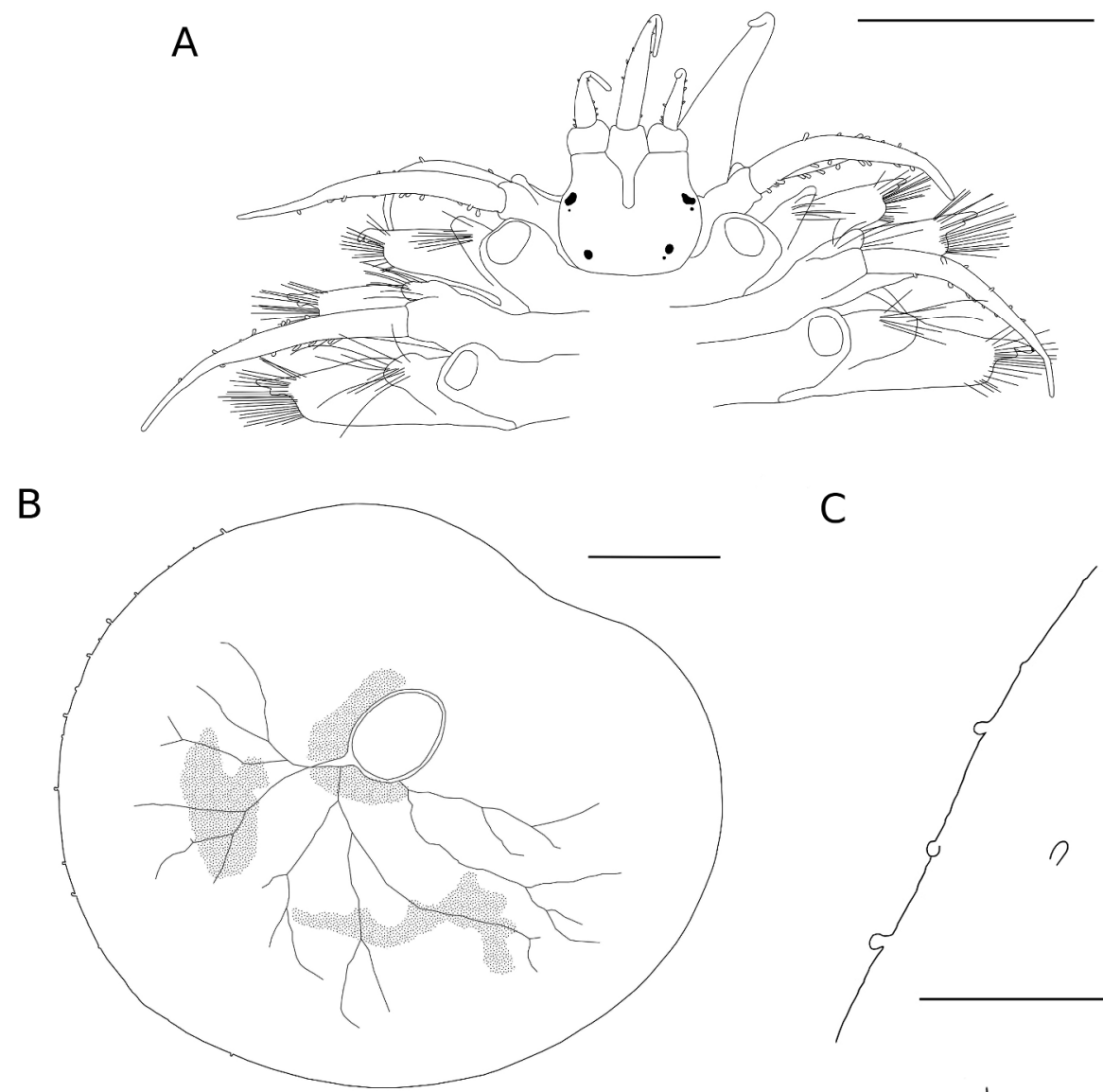

C
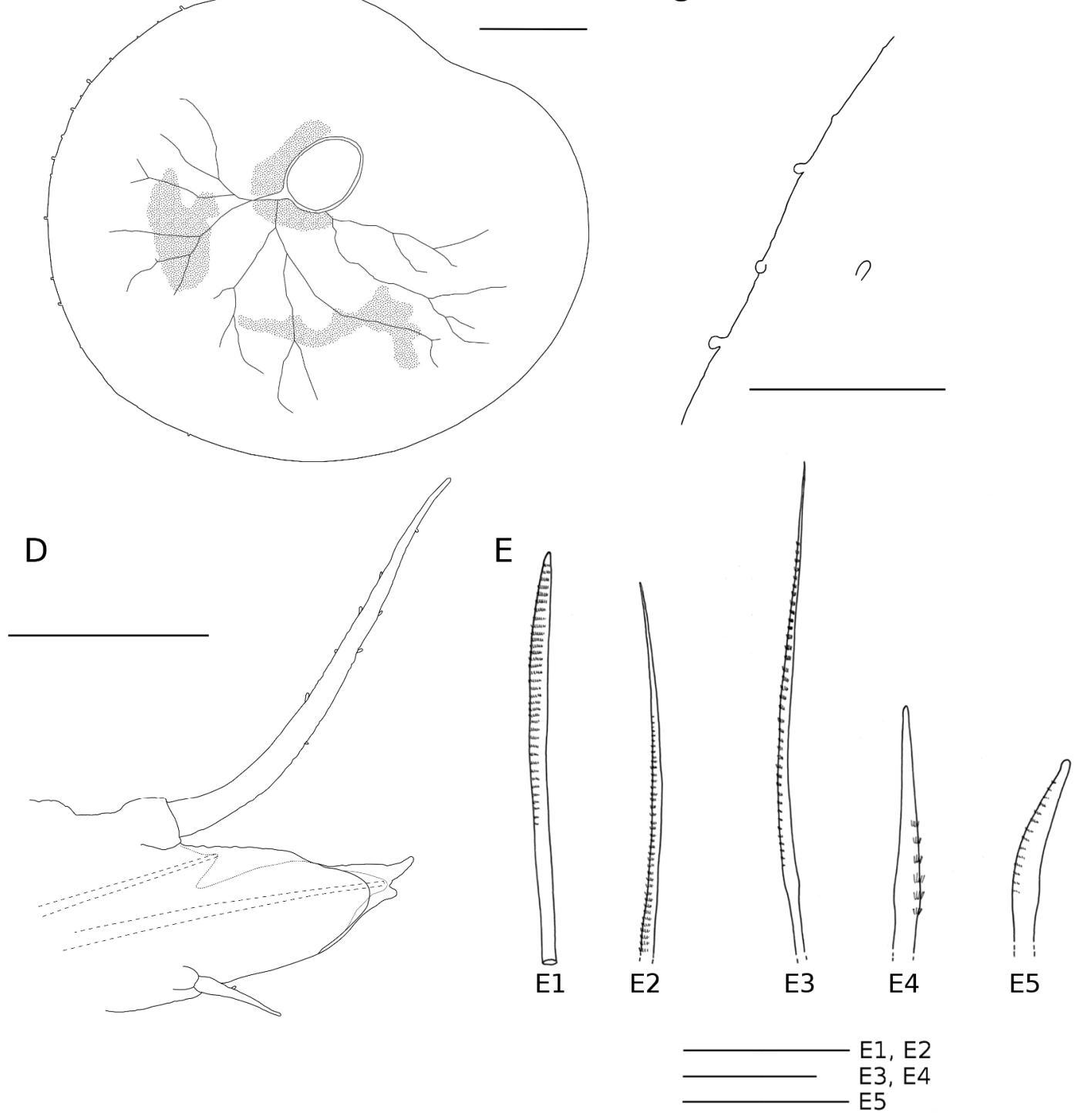